\title{
„Urzekli mnie moi uczniowie...”* - „Rocznik Andragogiczny” 2015, vol. 22, ss. 492
}

\section{Sukces „Rocznika”, czyli wprowadzenie}

„Rocznik Andragogiczny” jest podstawową lekturą dla pedagogów, którzy specjalizują się w edukacji dorosłych i chcą mieć przegląd najważniejszych i najbardziej aktualnych wydarzeń w badaniach i praktyce andragogicznej. Jak co roku, i tym razem - 22 numer „Rocznika” pozwala czytelnikom zapoznać się z najciekawszymi trendami, wynikami badań, badaczami, faktami i publikacjami z zakresu andragogiki. Teksty problemowe mieszczą się w czterech tradycyjnych działach pisma. Są to zatem analizy teoretyczne i badania edukacji dorosłych, teksty dotyczące edukacji dorosłych z międzynarodowej perspektywy, artykuły związane $z$ historią teorii i praktyki edukacji dorosłych oraz raporty z projektów edukacyjno-badawczych. Poza nimi w czasopiśmie znalazły się też aktualia i 17 recenzji książek z zakresu edukacji dorosłych. Należy dodać, co jednak nie zaskakuje, że każdy z zawartych w "Roczniku” tekstów jest na najwyższym merytorycznym poziomie, o co od lat dba redaktor naczelna pisma - prof. Hanna Solarczyk-Szwec. Pani Redaktor zaczyna tym razem od specjalnego Wprowadzenia, w którym pisze o dwóch ważnych faktach. Pierwszy z nich dotyczy statusu pisma wśród czasopism naukowych w Polsce. Solarczyk-Szwec pisze: „W 2015 r., w wyniku oceny przeprowadzonej przez Ministerstwo Nauki i Szkolnictwa Wyższego »Rocznik Andragogiczny« otrzymał 14 punktów na 15 możliwych na liście B czasopism. Pragniemy podziękować przy tej okazji Autorom, Recenzentom, Radzie Naukowej i Radzie Redakcyjnej za wysiłek, jaki wkładają w przygotowanie kolejnych tomów naszego pisma. Taki wynik nie tylko jest formą oceny naszej dotychczasowej pracy, ale przede wszystkim zobowiązuje do dalszych działań związanych z podnoszeniem jakości »Rocznika Andragogicznego«. W najbliższej przyszłości chcemy położyć szczególny nacisk na podniesienie współczynnika cytowalności oraz umiędzynarodowienie na-

* Tytuł jest zapożyczeniem z wywiadu Elżbiety Woźnickiej z prof. Olgą Czerniawską, opublikowany w „Roczniku Adragogicznym” 2015 (s. 23-38). 
szego pisma. Krokiem w tym kierunku było spełnienie warunków i włączenie w 2015 r. "Rocznika Andragogicznego" do międzynarodowej bazy czasopism ERIH+" (s. 11). Osiągnięcie to jest efektem ogromnej pracy redakcyjnej, która dba o prestiż czasopisma. Należy dodać, że czytelnikom redakcja oferuje otwarty i nieograniczony dostęp do treści zawartych od $2006 \mathrm{r}$. na Akademickiej Platformie Czasopism (www.apcz.pl).

Wprowadzenie zapowiada ponadto teksty poświęcone kilku jubileuszom prof. Olgi Czerniawskiej - 85 rocznicy urodzin, 60-leciu pracy naukowej oraz 20-leciu pracy zawodowej w Akademii Humanistyczno-Ekonomicznej w Łodzi. Należy przypomnieć, że poprzedni 21 tom „Rocznika Andragogicznego” zawierał teksty o jubileuszu prof. Józefa Półturzyckiego.

\section{Jubileusze prof. Olgi Czerniawskiej}

Profesor Olga Czerniawska jest aktywnym członkiem środowiska andragogicznego, współtwórczynią Akademickiego Towarzystwa Andragogicznego, członkiem Rady Naukowej „Edukacji Dorosłych” i „Rocznika Andragogicznego", autorką wielu cennych i cenionych publikacji z zakresu poradnictwa, andragogiki i geragogiki. Profesor była kierownikiem Zakładu Oświaty Dorosłych U€, Katedry Teorii Wychowania UŁ i Katedry Andragogiki AHE. W najnowszym tomie "RA” dorobek naukowy i zawodowy, a także nauczycielski i społecznikowski prof. Czerniawskiej przypominają różni autorzy.

Życiorys jubilatki przypomina Katarzyna Wypiorczyk-Przygoda w tekście Kalendarium biograficzne Profesor Olgi Czerniawskiej. Opisane są tu najważniejsze wydarzenia $\mathrm{z}$ życia prof. Czerniawskiej od momentu narodzin 4 kwietnia 1930 roku w Łodzi, ukończenie studiów na kierunku historia, obrona doktoratu w 1968 roku, habilitacja, uczestnictwo i współtworzenie najważniejszych naukowych organizacji, wydanie klasycznych już prac badawczych i podręczników czy udział w konferencjach naukowych (ostatnie wyróżnione wystąpienie miało miejsce w DSW we Wrocławiu w 2014 roku). Autorka prezentuje dokładnie drogę zawodową, m.in. początki pracy w Młodzieżowym Domu Kultury, Państwowym Studium Kulturalno-Oświatowym i Bibliotekarskim, Liceum dla Pracujących, a następnie na Uniwersytecie Łódzkim i w Akademii Humanistyczno-Ekonomicznej w Łodzi.

Niezwykle ciekawy dla biografistów i historyków jest także wywiad, jaki z prof. Czerniawską przeprowadziła Elżbieta Woźnicka, jej uczennica i długoletnia współpracowniczka. Tekst pt. Urzekli mnie moi uczniowie... osobiste refleksje we wspomnieniach Profesor Olgi Czerniawskiej zawiera liczne wspomnienia lat szkolnych i studenckich, szczególnie zaś lata działalności 
w stowarzyszeniach i pierwszej pracy, kiedy to spotyka ważne postacie na swoje drodze naukowej i osobistej: Marię Okońską, prof. Aleksandra Kamińskiego, ojca Tomasza Rostworowskiego czy nauczycieli historii: prof. Bokszańskiego, prof. Serejskiego, prof. Zajączkowskiego, prof. Wolskiego.

Ewa Skibińska natomiast przedstawia Księgę Jubileuszowq dla Profesor Olgi Czerniawskiej. Jest to 46 tom Biblioteki Edukacji Dorosłych, który tym razem ma wyjątkowy charakter. Publikację przygotowali bowiem przyjaciele, współpracownicy oraz uczniowie prof. Czerniawskiej. Całość obejmuje cztery części, które są zgodne z obszarami zainteresowań naukowych badaczki, i poprzedzona jest Wprowadzeniem autorstwa Elżbiety Woźnickiej redaktora tomu.

Pierwsza część nosząca tytuł „Olga Czerniawska - człowiek i dzieło” prezentuje biografię jubilatki i zainteresowania naukowe. Zawiera teksty Bogusława Śliwerskiego, Elżbiety Woźnickiej, Alicji Kargulowej, Józefa Kargula, Tadeusza Aleksandra i Hanny Solarczyk-Szwec. Druga część pt. „Andragogiczne peregrynacje” jest zbiorem tekstów poświęconych różnym problemom edukacji dorosłych autorstwa Józefa Półturzyckiego, Krzysztofa Pierścieniaka, Moniki Sulik, Joanny Stelmaszczyk, Ewy Trębickiej-Szumigraj, Joanny Szłapińskiej, Jiřego Pavlů, Joanny Madalińskiej-Michalak, Anny Panek i Anny Wrony, Andrzeja Pieczywoka, Tomasza Maliszewskiego. Część trzecia pt. „Wyzwania gerontologii społecznej” obejmuje teksty takich badaczy specjalizujących się w problematyce ludzi starszych, jak: Zofia Szarota, Leon Dyczewski, Małgorzata Dzięgielewska, Renata Konieczna-Woźniak, Artur Fabiś, Łukasz Tomczyk, Anna Jaroszewska, Agata Chabior czy Krzysztof Klimek. Ostatnia część dotyczy „Przemian poradnictwa”. Znajdują się w niej publikacje Elżbiety Siarkiewicz, Darii Zielińskiej-Pękał i Alicji Czerkawskiej.

Jednym z większych zasług prof. Czerniawskiej jest wykreowanie szkoły naukowej, której podstawą jest umiejętność współpracy, o czym pisze Józef Półturzycki w tekście Wartość wspótpracy naukowej. Profesor Półturzycki „Panią Profesor dr hab. Olgę Czerniawską poznał ponad 50 lat temu, gdy odwiedzał prof. Aleksandra Kamińskiego w jego katedrze na Uniwersytecie Łódzkim” (s. 51). Mistrzostwo prof. Czerniawskiej „Jest [...] przykład[em], jak wysoko ceniła swoich współpracowników i uczniów, wśród których wyrosła ceniona grupa specjalistów, tworzących wraz ze swoją Panią Profesor znane środowisko pedagogiki dorosłych w Uniwersytecie Łódzkim, a z czasem także w innych uczelniach tego miasta. Należy wymienić Panie: dr hab. Elżbietę Dubas-Kowalską, dr Barbarę Juraś-Krawczyk, dr Małgorzatę Dzię- 
gielewską, dr Elżbietę Woźnicką, dra Kazimierza Zawadzkiego i spore grono młodszej generacji andragogów" (s. 54).

Część jubileuszową „RA” kończy tekst Woźnickiej pt. Sprawozdanie i fotorelacja z seminarium naukowego "Oświata dorostych. Inspiracje i wyzwania" z okazji jubileuszu 85. urodzin, 60-lecia pracy naukowej oraz 20-lecia pracy $w$ Akademii Humanistyczno-Ekonomicznej w Łodzi prof. dr hab. Olgi Czerniawskiej. Jak pisze autorka, było to niezwykłe spotkanie, nie tylko naukowe, w którym uczestniczyła rodzina prof. Czerniawskiej: mąż, dzieci, wnuki, brali w nim także udział przyjaciele, uczniowie, zaproszeni goście, współpracownicy i studenci.

\section{Część merytoryczna „RA”, czyli edukacja dorosłych widziana z róż- nych perspektyw}

Po części wspomnieniowo-jubileuszowej w „Roczniku” znalazła się część I, w której można przeczytać teksty będące analizami teoretycznymi i relacjami z prowadzonych badań z zakresu edukacji dorosłych. Zawiera ona dziesięć tekstów. Łącznie w „RA” 2015 jest 20 tekstów, w tym prawie połowa jest obcojęzyczna. Osiem tekstów zostało napisanych w języku angielskim, jeden - w niemieckim.

Część I rozpoczyna ważny tekst teoretyczny Danuty Wajsprych pt. Od sporu o dwie etyki ku etyce niekonsensualnej. Autorka omawia dwa opozycyjne względem siebie paradygmaty etyczne - etykę tradycyjną (jej źródła tkwią w starożytnej filozofii racjonalistycznej i chrześcijańskiej teorii moralności) oraz etykę autentyczności (zakorzenioną $\mathrm{w}$ indywidualizmie ekspresywistycznym). Proponuje, by zażegnać spór między nimi i wprowadzić do pedagogiki oraz pedagogii etykę niekonsensualną, opartą na kategorii rozumienia:

W sytuacji wychowawczej przyjęcie dwóch etyk w izolacji oznacza: albo jesteś subiektywistą i mówisz „mogę, nie muszę”, albo obiektywistą i „musisz”, bo nie ma miejsca na „możesz”, zwłaszcza przy statycznej koncepcji człowieka. Tymczasem istnieją różne sposoby doświadczania świata oraz różne jego struktury sensotwórcze, a w wychowaniu nie chodzi o wykazywanie bezsensu jednego bądź drugiego stanowiska, lecz sensu i ograniczeń obydwu. Dlatego chcę utrzymywać, że istnieje inna możliwość lokująca nas poza horyzontem alternatywy albo-albo. Jest nią propozycja jednej etyki o dwóch biegunach, którą nazwijmy etyką niekonsensualną - etyką rozumienia" (s. 74). 
Być może propozycja Wajsprych okaże się potrzebna do rozważań nad biografiami (dorosłych) osób uczących się, które interpretują autorki trzech kolejnych tekstów w „RA”.

Tekst Alicji Jurgiel-Aleksander zatytułowany Jaka edukacja i dla kogo? Biografie edukacyjne dorostych $i$ ich społeczny wymiar nawiązuje do projektu realizowanego przez autorkę i opisanego w publikacji Doświadczenie edukacyjne w perspektywie andragogicznej. Studium biograficzno- fenomenograficzne (Gdańsk 2013). Badaczka próbuje zdiagnozować sytuację dorosłego jako osoby uczącej się, „odbywającą się na różne sposoby i wyrażaną w rozmaitych naukowych językach" (s. 80). Rekonstruuje prowadzone przez siebie badania oraz wprowadza kategorie analityczne, służące do zrozumienia biograficznych wypowiedzi badanych. Zaproponowane kategorie zinterpretowane są natomiast w kontekście używanego języka oraz dominującego (ekonomicznego) dyskursu publicznego. Szczególnie interesujący jest tu wątek „sposobu traktowania uczenia się jako kwestii publicznej widzianej oczami tych, którzy traktują ją jako cześć swojej codzienności i nadają jej swoje biograficzne znaczenia" (s. 99).

Podobny temat podejmuje Joanna Golonka-Legut w tekście Uczenie się w perspektywie biograficzności. Perspektywa andragogiczna. Artykuł został napisany przez autorkę na podstawie obronionej rozprawy doktorskiej „Potencjał edukacyjny doświadczenia życiowego osób starszych z perspektywy czasu", przygotowanej pod kierunkiem prof. dr hab. Elżbiety Kościk. Są to rozważania dotyczące głównie relacji procesu uczenia się i biograficzności oraz rozumienia biografii z perspektywy andragogicznej, odniesione do najważniejszych teorii z tego zakresu - autorstwa m.in. P. Dominicègo (2006), Czerniawskiej (2007a, 2007b, 2010, 2011), Dubas (2009, 2011, 2014, 2015a, 2015b), Skibińskiej (2006), D. Demetria (2000, 2009).

Problematykę powyższą kontynuuje Solarczyk-Szwec w tekście pt. Cztery ćwiartki biograficznego uczenia się. Jest to pogłębiona refleksja na temat biografii edukacyjnej prowadzona „w obszarach (czterech ćwiartkach) wyznaczonych przez kluczowe dla analizowanego zagadnienia wymiary rozpięte na osiach pomiędzy biograficznym uczeniem się jednostki oraz społeczeństwa/społeczności, a także świadomością i nieświadomością tego procesu, które zostały wygenerowane na podstawie analizy literatury przedmiotu" (s. 122).

Kolejny tekst pt. Praktyka integralna liderów oświaty. Aplikacja koncepcji Kena Wilbera został napisany przez duet - Beatę Przyborowską i Piotra Błajeta, w języku angielskim. Publikacja przedstawia teorię K. Wilbera (por. 2006) - tj. model czterech kwadrantów - ang. All Quadrants, która jest w za- 
łożeniach mapą terytorium ludzkiej aktywności. Mapa obejmuje nieredukowalne aspekty istnienia: intencjonalny - subiektywny, behawioralny obiektywny, społeczny - interobiektywny i kulturowy - intersubiektywny. Autorom koncepcja posłużyła do działań praktycznych, tj. wsparcia rozwoju osobistego i zawodowego dyrektorów szkół uczestniczących w studiach podyplomowych, realizowanych na Wydziale Nauk Pedagogicznych UMK.

Kolejnym anglojęzycznym tekstem jest praca Alicji Kozubskiej pt. Petnienie roli rodzica jako przestrzeń uczenia się dorostych. Autorka potraktowała proces stawania się rodzicem jako szansę do budowania konkretnych kompetencji życiowych np. porozumienie z drugim człowiekiem, efektywna komunikacja oparta na szacunku i zrozumieniu wartości autonomii i wolności. Katarzyna Jarosz w artykule Miejsce międzypokoleniowego uczenia się w procesie hominizacji również podjęła temat różnic pokoleniowych, jednak wykorzystując do tego klasyczną teorię trzech kultur Margaret Mead (kofiguratywnej, prefiguratynej i postfiguratywnej, por. 2000) oraz wymiary bycia i stawania się człowiekiem (biologiczny, społeczny, kulturowy, podmiotowo-osobowy, neotyczny) autorstwa Kazimierza Popielskiego (1994). Autorka prezentuje wyniki badań, jakie zostały przeprowadzone w województwie opolskim.

Tematem seniorów zajęła się Beata Stachowiak w anglojęzycznym tekście pt. Zagrożenia jednostki $w$ życiu osobistym i rodzinnym $w$ społeczeństwie informacyjnym $w$ opinii generacji 50+. Autorka wylicza, że we współczesnej Polsce żyje obok siebie sześć pokolen. Czy jednak potrafią się ze sobą komunikować, szczególnie w czasach zagrożeń i szans, jakie daje postęp technologiczno-informacyjny? By odpowiedzieć na to pytanie, autorka przeprowadziła badania na podstawie ponad 2 tysięcy ankiet.

Kontrowersyjne tematy podejmuje dwoje następnych autorów. Robert Opora w artykule pt. Sposoby spędzania czasu wolnego przez kobiety skazane na karę pozbawienia wolności jako potencjał do rozumienia znaczenia readaptacji społecznej prezentuje, jak ważna jest w życiu jednostki kategoria „czasu wolnego". Natomiast Małgorzata Henryka Kowalczyk w tekście pt. Prostytucja kobiet - świadomy wybór drogi życiowej czy przymus ekonomiczny analizuje czynniki, które wpływają na decyzję o uprawianiu prostytucji z włączeniem profilu osobowości i poziomu reaktywności (jest to tekst anglojęzyczny).

Drugą część „RA” 2015 stanowią cztery teksty związane z edukacją dorosłych w perspektywie porównawczej. Część tę rozpoczyna publikacja Hanny Kosyły pt. Kolonializm jako system wychowawczy. Na przykładzie sytuacji Brazylii - ojczyzny Paula Freirego. Autorka analizuje, w jaki sposób kolonializm jako kategoria zniewalająca, wpływa na proces wychowawczy 
Brazylijczyków. Czyni przez to życie bezwartościowym: „Kolonializm jako proces i system wychowawczy był długotrwały, całożyciowy i wielopokoleniowy. Oparty na przemocy. Użycie przemocy fizycznej było powszechnie obecne od początków kolonializmu. Z biegiem czasu rosło jednak znaczenie przemocy symbolicznej. Polegała ona głównie na zakorzenieniu dwudzielnej wizji świata skolonizowanych: my i kolonizatorzy; my i oni, my i tamci, my dobrzy i oni źli; my swoi i oni obcy" (s. 238).

Następny współautorski tekst stanowi analiza pt. Przekaz kulturowy w przestrzeni publicznej na przykładzie muzeów. Jej autorami są Ewa Przybylska oraz Ekkehard Nuissl. Badacze pokazują muzea jako specyficzne „miejsca pamięci", których zadaniem przekaz kultury. Zaznaczyć warto, że jest to tekst w języku niemieckim.

Perspektywę porównawczą stosują także autorzy kolejnego - anglojęzycznego - tekstu: Mariola Chomczyńska-Rubacha i Krzysztof Rubacha. Publikacja pt. Orientacje etyczne młodych kobiet $w$ Polsce i Serbii. Badania porównawcze dotyczy dwóch wyróżnionych przez autorów orientacji etycznych: na sprawiedliwość i na troskę. Beata Pietkiewicz-Pareek w tekście pt. "Iluzoryczna" walka $z$ analfabetyzmem dorostych $w$ Indiach - polityka oświatowa przedstawia założenia koncepcji edukacji fundamentalnej, którą Indie wprowadziły w latach 70. XX wieku pod egidą UNESCO (tekst jest w języku angielskim).

W trzeciej części „RA” zatytułowanej „Z historii teorii i praktyki edukacji dorosłych" czytelnik znajdzie także cztery artykuły. Agnieszka Stopińska-Pająk w publikacji pt. Polskie tradycje instytucji edukacji dorostych $w$ kontekście uczenia się catożyciowego opisuje korzenie i rozwój na polskich ziemiach różnych form kształcenia dorosłych: instytucje powiązane z ruchem samokształceniowym XIX wieku, Uniwersytet Latający, szkoły wyższe dla dorosłych, uniwersytety ludowe i świetlice dla dorosłych. Danuta Apanel i Tomasz Maliszewski są autorami anglojęzycznego tekstu pt. Implementacja koncepcji edukacji ustawicznej w polskim prawie o szkolnictwie wyższym przed rokiem 1989. Zarys problematyki. W tekście przedstawiono zbiór przepisów prawnych zawartych w polskim prawie o szkolnictwie wyższym z okresu dwudziestolecia międzywojennego oraz z czasów Polskiej Rzeczypospolitej Ludowej (1945-1989), które są przykładami realizacji w uczelniach wyższych koncepcji LLL. Tadeusz Aleksander w tekście pt. Odnowiona pamięć o Andrzeju Niesiołowskim i jego twórczości naukowej w obszarze teorii kształcenia dorosłych przypomina sylwetkę wybitnego twórcy prac z zakresu z zakresu socjologii, pedagogiki, polityki społecznej, teorii edukacji dorosłych. Dział ten zamyka artykuł Małgorzaty Stawiak-Ososińskiej pt. Kształcenie akusze- 
rek w Wilnie w czasach Szkoły Głównej Wielkiego Księstwa Litewskiego i Szkoły Głównej Litewskiej (1780-1803). Autorka opowiada o trudnych warunkach, w jakich prowadzono kształcenie położnych na ówczesnych ziemiach polskich, gdyż np. „Warunkiem zorganizowania nauczania sztuki położniczej było nie tylko zapewnienie miejsca do odbywania wykładów i odpowiedniego profesora, ale przede wszystkim stworzenie klinik, w których potencjalni uczniowie, uczennice mogliby praktycznie uczyć się jak należy prawidłowo postępować podczas porodu. Zarówno w Krakowie, jak i Wilnie odbyło się to przez adaptację jednego pomieszczenia w istniejącym w mieście szpitalu, w którym jednocześnie funkcjonowały inne kliniki medyczne” (s. 327).

Artykuły z części IV mają charakter sprawozdawczy, są to bowiem „Raporty z projektów edukacyjno-badawczych”. Joanna Krystyna Wawrzyniak w tekście pt. Specjalna Strefa Demograficzna obszarem dobrych praktyk na rzecz seniorów. Założenia i realizacja programu pisze o specjalnym projekcie, ustanowionym przez zarząd województwa opolskiego 14 września 2014 r., mającym na celu przeciwdziałania niekorzystnym zjawiskom społecznym (demograficznym, ekonomicznym, gospodarczym, zawodowym). Głównie chodzi w nim o zapobieganie zjawisku depopulacji w długiej perspektywie oraz wsparcie seniorów. Autorka opisuje szczegóły programu, ocenia je oraz pokazuje dobre praktyki. Natomiast Przemysław Ziółkowski w anglojęzycznym tekście pt. Teoria Marka Savickasa jako inspiracja dla doradztwa zawodowego dorostych na przykładzie metody gier diagnostyczno-symulacyjnych prezentuje założenia i realizację projektu „Od diagnozy do działania”. Ten innowacyjny projekt polegał na wykorzystaniu teorii gier w procesie poradnictwa zawodowego i budowania kariery zawodowej.

\section{Co się dzieje... czyli „Aktualia”}

Z punktu widzenia socjologii wiedzy szczególnie ciekawe są teksty zawarte w dziale V „Aktualia”. Są to informacje o rozwoju subdyscypliny: awanse zawodowe, w tym obrony doktoratów i postępowania habilitacyjne, sprawozdania z konferencji, ale też wydarzenia smutne - pożegnania osób związanych z edukacją dorosłych i jej pokrewnymi dziedzinami.

W 2015 r. trzy osoby obroniły doktoraty z zakresu andragogiki: Katarzyna Jarosz, Henryka Radziejowska, Piotr Szpakowski. W latach 2015-2016 odeszły dwie wybitne profesor pedagogiki: prof. Eugenia Anna Wesołowska i prof. Eugenia Malewska.

Należy ocenić bardzo pozytywnie intensywną działalność konferencyjną andragogów, o czym świadczy aż 10 sprawozdań ze spotkań naukowych 
umieszczonych „Roczniku”. „Aktualia” kończą się sprawozdaniem Tomasza Maliszewskiego z działalności Zarządu Akademickiego Towarzystwa Andragogicznego w 2015 roku.

Dział VI „Rocznika” obfituje w recenzje książek, które poruszają kwestie z obszaru edukacji dorosłych. Taka liczba publikacji (15 tytułów) świadczy o niewątpliwym rozwoju subdyscypliny. Część z nich jest anglojęzyczna, kilka $\mathrm{z}$ nich to prace zbiorowe.

\section{Zakończenie}

Ostatnim tekstem 22 tomu jest felieton Józefa Półturzyckiego pt. „Rok 2015". Autor dokonuje przeglądu najważniejszych wydarzeń w historii Polski i świata. Stwierdza: „W Polsce dokonały się nowe zmiany zapowiadane jako dobre. Wybrano nowego prezydenta, Sejm i Rząd Rzeczypospolitej. Poprzednia epoka odchodzi do historii, w cień i, co gorzej, w niechlubne zapomnienie. Rok $15 \mathrm{w}$ poprzednich stuleciach oraz 50 -leciach był dla nas ważny, chociaż nie zawsze pomyślny. Sięgnijmy do przeszłości, kiedy pewne ważne wydarzenia odbyły się także 100, 200 lat temu, a nawet 600, gdy urodził się Jan Długosz" (s. 486).

Zwykle ocena tomów zbiorowych jest trudna i niejednoznaczna. Dzieje się tak ze względu na różnorodność (tematów) tekstów, (języka) autorów, (wagi) problemów. W przypadku „Rocznika” trudność ta jest znacznie ograniczona dzięki przemyślanej konstrukcji i znakomitej redakcji całości. Teksty są ciekawe, merytorycznie na wysokim poziomie, a co ważne - potrzebne. $Z$ całym przekonaniem należy stwierdzić, że jest to lektura dla każdego nie tylko andragoga, ale i pedagoga, który chce być zorientowany w najnowszych kwestiach edukacji dorosłych i jej pokrewnych - gerontologii czy też poradoznawstwa.

Anna Maria Kola

\section{Bibliografia}

Czerniawska O. (2007a), Drogi i bezdroża andragogiki i gerontologii. Szkice i rozprawy, Wydawnictwo Wyższej Szkoły Humanistyczno-Ekonomicznej, Łódź.

Czerniawska O. (2007b), Szkice z andragogiki i gerontologii, Wydawnictwo Wyższej Szkoły Humanistyczno-Ekonomicznej, Łódź. 
Czerniawska O., Rola marzeń w życiu ludzi starszych, „Rocznik Andragogiczny” 2010, s. 107-113.

Czerniawska O. (red.) (2011), Andragogiczny wymiar wydarzeń osobistych i globalnych w badaniach biograficznych, Wydawnictwo Wyższej Szkoły Humanistyczno-Ekonomicznej, Łódź.

Demetrio D. (2000), Autobiografia. Terapeutyczny wymiar pisania o sobie, Wydawnictwo Impuls, Kraków.

Demetrio D. (2009), Pedagogika pamięci. W trosce o nas samych, z myślą o innych, Wydawnictwo Akademii Humanistyczno-Ekonomicznej, Łódź.

Dominicé P. (2006), Uczyć się z życia. Biografia edukacyjna w edukacji dorosłych, Wydawnictwo Wyższej Szkoły Humanistycznej, Łódź.

Dubas E. (2009), Refleksja autobiograficzna jako aktywność edukacyjna w kontekście całożyciowego uczenia się, [w:] A. Fabiś, S. Kędziora (red.), Wyzwania współczesnej edukacji dorostych: Aktywność społeczna, kulturalna i oświatowa dorostych, Wydawnictwo Górnośląskiej Wyższej Szkoły Pedagogicznej im. Kardynała A. Hlonda, Mysłowice-Zakopane, s. 41-53.

Dubas E. (2011), Uczenie się z (własnej) biografii - wprowadzenie, [w:] E. Dubas, W. Świtalski (red.), Uczenie się z (własnej) biografii, Wydawnictwo Uniwersytetu Łódzkiego, Łódź, s. 5-9.

Dubas E. (2014), Edukacja $w$ andragogicznych badaniach biograficznych - biografia edukacyjna, [w:] R. Skrzyniarz, E. Krzewska, W. Zgłobicka-Gierut, Badanie biografii -źródła, metody, konteksty, Wydawnictwo Episteme, Lublin, s. 17-31.

Dubas E. (2015a), Andragogiczne badania biografii - zakresy, trudności, etyka badacza (wybrane aspekty), [w:] E. Dubas, J. Stelmaszczyk (red.), Biografie i uczenie się, Wydawnictwo Uniwersytetu Łódzkiego, Łódź, s. 32-47.

Dubas E. (2015b), Biograficzność w kontekście całożyciowego uczenia się, [w:] E. Dubas, J. Stelmaszczyk, Biografie i uczenie się, Wydawnictwo Uniwersytetu Łódzkiego, Łódź, s. 11-29.

Jurgiel-Aleksander A. (2013), Doświadczenie edukacyjne w perspektywie andragogicznej. Studium biograficzno-fenomenograficzne, Wydawnictwo Uniwersytetu Gdańskiego, Gdańsk.

Mead M. (2000), Kultura i tożsamość. Studium dystansu międzypokoleniowego, Wydawnictwo Naukowe PWN, Warszawa.

Popielski K. (1994), Neotyczny wymiar osobowości, Redakcja Wydawnictw KUL, Lublin.

Skibińska E. M. (2006), Mikroświaty kobiet. Relacje autobiograficzne, Wydawnictwo Naukowe Instytutu Technologii Eksploatacji, Radom.

Wilber K. (2006), Psychologia integralna, Wydawnictwo Czarna Owca, Warszawa. 